\title{
REGULATORY OFF-GAS ANALYSIS FROM THE EVAPORATION OF HANFORD SIMULATED WASTE SPIKED WITH ORGANIC COMPOUNDS
}

\author{
Hiroshi H. Saito, T. Bond Calloway, Jr., Daro M. Ferrara, Alexander S. Choi, Thomas L. White \\ Westinghouse Savannah River Company \\ Savannah River Technology Center
}

Aiken, SC 29808

Luther V. Gibson, Jr., Mark A. Burdette

BWXT-Y12, L. L. C.

Bldg. 9995, MS 8189

Oak Ridge, TN 37831

Prepared for Presentation at the

2001 American Institute of Chemical Engineers Spring National Meeting

April 25, 2001

Novel Chemical Processing for Nuclear Materials Reclamation, Stabilization, and Storage: Part II

Copyright $\odot$ H. H. Saito, T. B. Calloway, D. M. Ferrara, T. L. White, A. S. Choi, Westinghouse Savannah River Company

L. V. Gibson, Jr., M. A. Burdette, BWXT-Y12, L. L. C.

Unpublished

AIChE shall not be responsible for statements or opinions contained in papers or printed in its publications 
This document was prepared in conjunction with work accomplished under Contract No.

DE-AC09-96SR18500 with the U.S. Department of Energy.

\section{DISCLAIMER}

This report was prepared as an account of work sponsored by an agency of the United States Government. Neither the United States Government nor any agency thereof, nor any of their employees, makes any warranty, express or implied, or assumes any legal liability or responsibility for the accuracy, completeness, or usefulness of any information, apparatus, product or process disclosed, or represents that its use would not infringe privately owned rights. Reference herein to any specific commercial product, process or service by trade name, trademark, manufacturer, or otherwise does not necessarily constitute or imply its endorsement, recommendation, or favoring by the United States Government or any agency

thereof. The views and opinions of authors expressed herein do not necessarily state or reflect those of the United States Government or any agency thereof.

This report has been reproduced directly from the best available copy.

Available for sale to the public, in paper, from: U.S. Department of Commerce, National Technical Information Service, 5285 Port Royal Road, Springfield, VA 22161, phone: (800)

553-6847, fax: (703) 605-6900, email: orders@ntis.fedworld.gov online ordering: http://www.ntis.gov/ordering.htm

Available electronically at http://www.doe.gov/bridge

Available for a processing fee to U.S. Department of Energy and its contractors, in paper, from: U.S. Department of Energy, Office of Scientific and Technical Information, P.O. Box 62, Oak Ridge, TN 37831-0062, phone: (865 ) 576-8401, fax: (865) 576-5728, email: reports@ adonis.osti.gov 


\section{INTRODUCTION}

The Hanford River Protection Project Waste Treatment Plant (RPP-WTP) pretreatment and immobilization process will decontaminate Envelope A, B \& C supernatant liquids using cesium and technetium ion exchange columns, after strontium and transuranics ( $\mathrm{Sr} / \mathrm{TRU}$ ) are removed via a precipitation (Envelope $\mathrm{C}$ only) and filtration step. The decontaminated low activity waste (LAW) will be concentrated through the LAW Melter Feed Evaporator, a forced circulation evaporator, before glass formers are added and the resulting slurry vitrified in a joule-heated, refractorylined melter. The purposes of this work were to: 1) develop preliminary operating data such as expected concentration endpoints for flow sheet development and evaporator design, and 2) examine the regulatory off-gas emission impacts from the evaporation of relatively organic-rich Hanford Tank 241-AN-107 Envelope C waste simulant containing 14 volatile, semi-volatile and pesticide organic compounds potentially present in actual Hanford RPP waste. The latter results will be used as input into RPP-WTP environmental permits and risk assessments. This work also served as the working basis for Crawford et al. (Paper 108a).

\section{EXPERIMENTAL}

To minimize potential organic absorption/adsorption losses, a bench-scale thermosiphon evaporator constructed mainly of glass and polytetrafluoroethylene (PTFE) was used (Figure 1). Thermocouples and resistance temperature detectors measured the evaporator (T2), condensor (T3) and condensate (T4) temperatures, and an Incoloy ${ }^{\circledR}$ heating rod (with internal thermocouple T1) served as the heating element in this natural circulation evaporator. Pressure (PG) and temperature measurement devices as well as material addition/removal ports were secured using stainless steel fittings mounted in PTFE plugs. Feed, condensate and concentrate were introduced or removed from the system through PTFE lines and valves (V1-V3). Continuous feed addition and concentrate removal (semi-batch for condensate) was performed using peristaltic pumps equipped with a segment of Viton ${ }^{\circledR}$ tubing. Natural leak rates of as low as $0.2 \mathrm{~mL} / \mathrm{min}$ (STP) were achieved for this $\sim 5200 \mathrm{~mL}$ internal volume system. A measured air in-leakage was added using a mass-flow controller to create a total evaporator in-leakage $(11.5 \mathrm{ml} / \mathrm{min})$ scaled for expected air in-leakage in the full-scale plant. AN-107 simulated waste feed material (5.5 M Na) was introduced into the evaporator from 1L polyvinyl fluoride (PVF) bags, after being injected with an acetone spiking solution containing 14 target volatile, semi-volatile, and pesticide compounds to a target of $1 \mathrm{ppm}$ (similar to maximum concentrations 


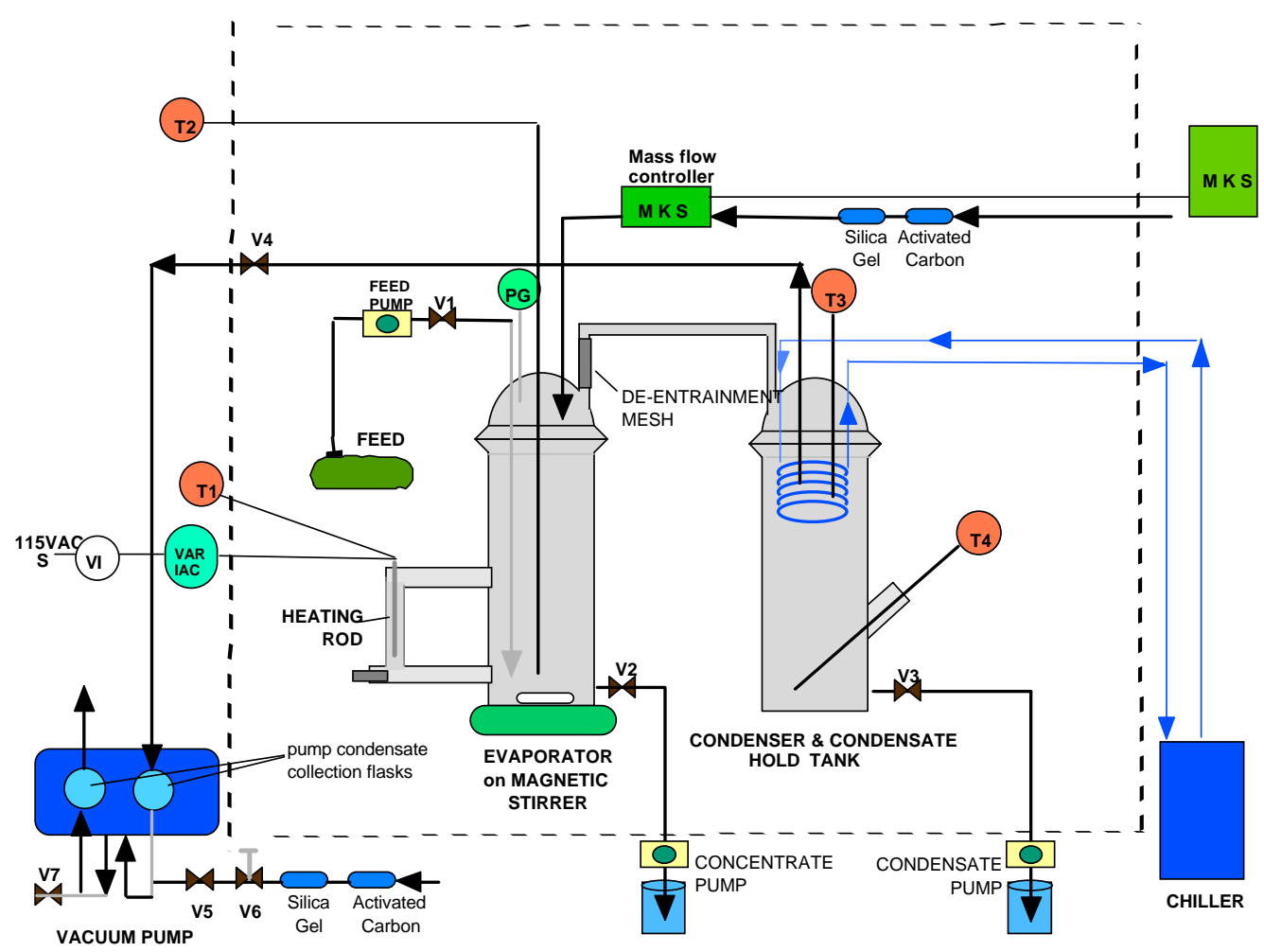

Figure 1. Evaporator System Schematic

in actual waste [Klinger et al., 2000]). Anti-entrainment of liquid to $>99 \%$ was achieved using a rolled stainless steel mesh mounted above the evaporator.

The total evaporator off-gas and PTFE-diaphragm vacuum pump bleed air, used to adjust evaporator pressure, were sent to a volatile organic sampling train coupled with a metering console that is designed for use for Environmental Protection Agency (EPA) SW-846 Methods 0010 and 0031 required this work. Two Tenax ${ }^{\circledR}$-GC and one Anasorb ${ }^{\circledR}-747$ sorbent tube were mounted in the off-gas sampler for volatiles sampling (Method 0031), and a single XAD- $2^{\circledR}$ sorbent tube for the semi-volatiles/pesticide sampling (Method 0010). After an initial boildown to raise the evaporator concentration from 5.5 to $8.0 \mathrm{M} \mathrm{Na}$, steady state operation $\left(50 \pm 3^{\circ} \mathrm{C}, 60 \pm 8 \mathrm{~mm} \mathrm{Hg}, 40 \pm 1^{\circ} \mathrm{C}\right.$ condensor) was performed for $\sim 75$ hours continuously, with the total run time divided equally between each off-gas sampling method. For a post-experiment material balance, regulatory liquid samples were collected simultaneously with the off-gas samples, and together were sent to a vendor laboratory for EPA SW-846 regulatory analysis. 


\section{RESULTS AND DISCUSSION}

Mass balance closure on the 75 hour steady-state evaporation was to within $2 \%$ by mass overall, with closures to within $5 \%$ and $1 \%$ for the volatiles and semi-volatiles off-gas sampling portions of the run, respectively. Table 1 shows that material balance results for each of the 14 target organic compounds were generally well within the customer-approved 20-130\% recovery (-30 to 80\% mass closure), except 1,2-dibromoethane, 1,2,3-trichloropropane and pentachlorophenol where measured small quantities and large analytical losses are expected due to hydrolysis.

\begin{tabular}{|c|c|c|c|c|c|c|c|c|c|}
\hline & Chemical & $\begin{array}{c}\text { Mass } \\
\text { Fed (ug) }\end{array}$ & Condensate & Concentrate & $\begin{array}{c}\text { Sorbent } \\
\text { Tube }\end{array}$ & \begin{tabular}{|l|} 
Pump \\
Traps
\end{tabular} & $\begin{array}{c}\text { Off-gas } \\
\text { Line Rinse }\end{array}$ & TOTAL & $\begin{array}{c}\text { Mass } \\
\text { Closure (\%) }\end{array}$ \\
\hline \multirow{6}{*}{ 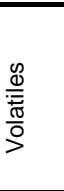 } & Benzene & 55550 & 405 & $174^{*}$ & 49896 & $15^{\star}$ & 0 & 50491 & 9.11 \\
\hline & 4-methyl-2-pentanone (MIBK) & 99928 & $2063^{*}$ & $1833^{*}$ & 66401 & $373^{*}$ & 0 & 70670 & 29.28 \\
\hline & Toluene & 41386 & 326 & $235^{*}$ & 22736 & $10^{*}$ & 0 & 23307 & 43.68 \\
\hline & 1,2-dibromoethane & 2821 & 523 & $55^{*}$ & 9335 & $24^{*}$ & 0 & 9938 & -252.25 \\
\hline & Chlorobenzene & 45660 & 554 & $166^{*}$ & 17811 & $11^{*}$ & 0 & 18542 & 59.39 \\
\hline & 1,2,3-trichloropropane & 38471 & $2139^{*}$ & $6222^{*}$ & 0 & $34^{*}$ & 0 & 8395 & 78.18 \\
\hline \multirow{7}{*}{ 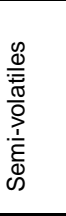 } & 1,2,4-trichlorobenzene & $22927^{*}$ & 1000 & $1508^{*}$ & 19599 & 130 & 0 & 22238 & 3.01 \\
\hline & Naphthalene & $22021^{*}$ & 3712 & $683^{*}$ & 17024 & 448 & 0 & 21867 & 0.69 \\
\hline & Hexachlorobenzene & 31574 & 22 & $22522^{*}$ & 0 & $0^{*}$ & 940 & 23483 & 25.62 \\
\hline & Pentachlorophenol & 2332 & 0 & 4058 & 0 & $0^{*}$ & 0 & 4058 & -74.04 \\
\hline & Pyrene & $36140^{*}$ & 1699 & $20425^{*}$ & 0 & $28^{*}$ & 719 & 22870 & 36.72 \\
\hline & Bis(ethylhexyl)phthalate (BEHP) & 40220 & 38 & $24618^{*}$ & 0 & 0 & 0 & 24656 & 38.70 \\
\hline & Benzo[a]pyrene (BaP) & $56735^{\star}$ & 0 & $31449^{*}$ & 0 & $0^{*}$ & 0 & 31449 & 44.57 \\
\hline \multirow[t]{2}{*}{\begin{tabular}{|l}
$\begin{array}{r}\text { Pest- } \\
\text { icide }\end{array}$ \\
\end{tabular}} & Aldrin & $40285^{\star}$ & 315 & $31449^{*}$ & 0 & $18^{*}$ & 0 & 31782 & 21.11 \\
\hline & Theoretical (each) & 50518 & & & & Ana & ical Result & & \\
\hline
\end{tabular}

Table 1. Overall Mass Balance for Each Target Organic Compound

Excellent evaporator performance was evidenced by non-detectable levels $(<0.01-10 \mathrm{mg} / \mathrm{L})$ of metals (except $\mathrm{Si}$ ) and anions in the condensate when analyzed by induced-coupled plasma emission spectroscopy (ICP-ES) and anion ion chromatography (IC). When more sensitive analytical methods such as ICP-mass spectroscopy (ICP-MS) and $\mathrm{pH}$ were used, decontamination factors $\left(\mathrm{DF}=\right.$ feed concentration/condensate concentration) of $10^{5}$ were obtained for Cs and free hydroxide, respectively, confirming quality of performance.

The overall mass balance data indicate the feed was concentrated by a factor of 1.42 (Table 2), assuming ideal mixing and that the condensate is pure water. Combining this concentration factor with evaporator feed data, predicted species concentrations in the concentrate were calculated (Table 2). Given the estimated 10\% random error in the analytical data, the actual and predicted concentrate metals and total solids concentrations match very well, being within $12 \%$ for the majority of analytes except Si and Zr. The good comparisons for the major and/or highly soluble nitrate, total hydroxide, formate and total organic carbon suggest analytical error which could account for up to $20 \%$ of the difference is not a major factor, although error in nitrite indicates the contrary. Overall, Table 2 indicates that the Envelope C simulant generally appears to behave like an ideal mixture in this concentration range, 


\begin{tabular}{|c|c|c|c|c|c|}
\hline Property/Analyte & \multicolumn{2}{|c|}{$\begin{array}{c}\text { Measured } \\
\text { Feed (basis) }\end{array}$} & $\begin{array}{c}\text { Measured } \\
\text { Concentrate }\end{array}$ & $\begin{array}{c}\text { Volume Additivity } \\
\text { Concentrate Prediction }\end{array}$ & $\begin{array}{l}\% \text { Difference } \\
\text { vs. Measured }\end{array}$ \\
\hline $\mathrm{Al}(\mathrm{mg} / \mathrm{L})$ & 236 & 223 & 328 & 325 & 0.9 \\
\hline $\mathrm{B}(\mathrm{mg} / \mathrm{L})$ & 23 & 22 & 28.7 & 31.9 & 11.0 \\
\hline $\mathrm{Ca}(\mathrm{mg} / \mathrm{L})$ & 160 & 143 & 202 & 215 & 6.2 \\
\hline $\mathrm{Cu}(\mathrm{mg} / \mathrm{L})$ & 13 & 13 & 17.5 & 18.4 & 5.2 \\
\hline $\mathrm{Fe}(\mathrm{mg} / \mathrm{L})$ & 34 & 35 & 47.0 & 48.8 & 3.9 \\
\hline $\mathrm{Mn}(\mathrm{mg} / \mathrm{L})$ & 11 & 24 & 22.4 & 24.8 & 10.6 \\
\hline Mo (mg/L) & & 20 & 30.2 & 28.3 & 6.2 \\
\hline $\mathrm{Na}(\mathrm{mg} / \mathrm{L})$ & $\begin{array}{c}12525 \\
8 \\
\end{array}$ & $\begin{array}{c}13105 \\
7 \\
\end{array}$ & 184200 & 181460 & 1.5 \\
\hline $\mathrm{Si}(\mathrm{mg} / \mathrm{L})$ & 8 & 9.2 & 19.8 & 12.2 & 38.5 \\
\hline $\mathrm{Sr}(\mathrm{mg} / \mathrm{L})$ & 80 & 73 & 106 & 108 & 2.2 \\
\hline $\mathrm{Zn}(\mathrm{mg} / \mathrm{L})$ & 18 & 17 & 24.8 & 24.8 & 0.1 \\
\hline $\mathrm{Zr}(\mathrm{mg} / \mathrm{L})$ & 2 & 1.7 & 1.9 & 2.6 & 37.9 \\
\hline Chloride (mg/L) & 1308 & 2477 & 1559 & 2680 & 71.9 \\
\hline Fluoride (mg/L) & 2864 & 2455 & 3177 & 3766 & 18.5 \\
\hline Formate (mg/L) & 7179 & 6636 & 10105 & 9780 & 3.2 \\
\hline Nitrate $(\mathrm{mg} / \mathrm{L})$ & $\begin{array}{c}14518 \\
6 \\
\end{array}$ & $\begin{array}{c}13796 \\
1 \\
\end{array}$ & 188331 & 200456 & 6.4 \\
\hline Nitrite $(\mathrm{mg} / \mathrm{L})$ & 38751 & 36145 & 42364 & 53023 & 25.2 \\
\hline Oxalate (mg/L) & 1578 & 1306 & 1647 & 2042 & 24.0 \\
\hline Phosphate (mg/L) & 1529 & 2349 & 2148 & 2745 & 27.8 \\
\hline Sulfate $(\mathrm{mg} / \mathrm{L})$ & 5273 & 5297 & 5913 & 7483 & 26.6 \\
\hline Total $\mathrm{OH}^{-}(\mathrm{M})$ & 1.395 & 1.421 & 2.059 & 1.994 & 3.2 \\
\hline Free $\mathrm{OH}^{-}(\mathrm{M})$ & 0.553 & 0.561 & 0.987 & 0.789 & 20.1 \\
\hline Total Inorganic C (mg/L) & & & 15046 & 24795 & 64.8 \\
\hline Total Organic C (mg/L) & & & 17328 & 15674 & 9.5 \\
\hline $\mathrm{Na}(\mathrm{M})$ & & & 8.01 & 7.90 & 1.5 \\
\hline Tot. Solids (wt\%) & & & 42.9 & 42.5 & 0.9 \\
\hline Total Mass Processed (g) & & & 37874 & Conc. Factor & \\
\hline Total Volume Processed (mL) & & & 27445 & 1.42 & \\
\hline Assumed Density $(\mathrm{g} / \mathrm{mL})$ & & & 1.38 & $\begin{array}{ll}---- \\
--1\end{array}$ & \\
\hline
\end{tabular}

Table 2. Actual concentrate metal and anion concentrations versus prediction by volume additivity (ideal mixing behavior).

within measurement error. A similar analysis with concentrate samples taken after a "final" boildown to a "saturated" solution yielded the same results. Good comparison of simulant composition after steady state evaporation with expected Hanford waste concentrations was also found [Fiskum et al., 2000]. During the "final" boildown of an aliquot of $~ 8.3 \mathrm{M} \mathrm{Na}$ concentrate, evaporator contents within a 1-2 minute period transitioned from a green semi-translucent liquid to a very viscous greenish-white gel at a calculated $10.1 \mathrm{M} \mathrm{Na}$, corresponding to bulk saturation at $48.6 \mathrm{wt} \%$ total solids $\left(94.6 \mathrm{~g}\right.$ TS per $100 \mathrm{~g}$ water) at $50^{\circ} \mathrm{C}$.

Modeling using the OLI Environmental Simulation Program (ESP) successfully predicted conditions suitable for steady state evaporation, predicted bulk saturation at >11 M Na, and generally correctly predicted the relative partitioning of each target organic between condensate, concentrate and off-gas (Table 3). As the model predicted a separate organic phase in all aqueous streams, secondary interactions between water and acetone (from the spiking solution) assisting dissolution of heavier semivolatiles were likely not taken into account, leading to the 


\begin{tabular}{|c|c|c|c|c|c|c|c|c|}
\hline & & \multicolumn{6}{|c|}{$\%$ of total feed } & \multirow{2}{*}{$\begin{array}{c}\text { Condensor } \\
\text { Vent } \\
(\mathrm{ug} / \mathrm{g}) \\
\end{array}$} \\
\hline & & \multicolumn{3}{|c|}{ EXPERIMENTAL DATA } & \multicolumn{3}{|c|}{ OLI Model Prediction } & \\
\hline \multirow{6}{*}{$\frac{\frac{0}{\pi}}{\frac{\underline{T}}{0}}$} & Benzene & 0.7 & $0.3^{*}$ & 89.8 & 0.4 & 0.0 & 99.5 & 723 \\
\hline & 4-methyl-2-pentanone (MIBK) & $2.1^{*}$ & $1.8^{*}$ & 66.8 & 11.9 & 0.2 & 87.9 & 963 \\
\hline & Toluene & 0.8 & $0.6^{*}$ & 55.0 & 0.4 & 0.0 & 99.6 & 330 \\
\hline & 1,2-dibromoethane & 18.6 & $2.0^{*}$ & 331.7 & 3.5 & 0.1 & 96.4 & 135 \\
\hline & Chlorobenzene & 1.2 & $0.4^{*}$ & 39.0 & 0.9 & 0.0 & 99.1 & 258 \\
\hline & 1,2,3-trichloropropane & $5.6^{*}$ & $16.2^{*}$ & 0.1 & 4.9 & 0.1 & 95.1 & 0 \\
\hline \multirow{7}{*}{ 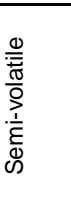 } & 1,2,4-trichlorobenzene & 4.4 & $6.6^{*}$ & 86.1 & 0.9 & 0.0 & 99.0 & 315 \\
\hline & Naphthalene & 16.9 & $3.1^{*}$ & 79.3 & 2.8 & 0.0 & 97.2 & 274 \\
\hline & Hexachlorobenzene & 0.1 & $71.3^{*}$ & 3.0 & 0.0 & 100.0 & 0.0 & 0 \\
\hline & Pentachlorophenol & 0.0 & 174.0 & 0.0 & 77.8 & 19.4 & 2.8 & 0 \\
\hline & Pyrene & 4.7 & $56.5^{*}$ & 2.1 & 88.3 & 6.0 & 5.6 & 0 \\
\hline & Bis(ethylhexyl)phthalate (BEHP) & 0.1 & $61.2^{*}$ & 0.0 & 12.6 & 87.4 & 0.0 & 0 \\
\hline & Benzo(a)pyrene & 0.0 & $55.4^{*}$ & 0.0 & 0.0 & 100.0 & 0.0 & 0 \\
\hline $\begin{array}{l}\text { Pest- } \\
\text { icide }\end{array}$ & Aldrin & 0.8 & $78.1^{*}$ & 0.0 & 67.7 & 31.3 & 1.0 & 0 \\
\hline
\end{tabular}

Table 3. Experimental and OLI Model Predicted Organics Distribution as a Percentage of Each Species Fed.

exceptions pyrene, pentachlorophenol and Aldrin. By dividing total quantities of volatilized species detected in the off-gas samplers by total mass of air in-leaked $(11.5 \mathrm{~mL} / \mathrm{min})$, target organic compound concentrations in the evaporator condensor vent stream as high as $\sim 1000 \mathrm{ppm}$ were found.

\section{CONCLUSIONS}

The following was found from the regulatory off-gas sampling from the evaporation of Hanford RPP Tank AN-107

(Envelope C) simulated waste spiked with 14 (1.03 ppm theoretical concentration) volatiles, semi-volatiles, and pesticide target compounds: 1) volatiles and light semi-volatiles (1,2,4-trichlorobenzene and naphthalene) almost completely exit through the evaporator condensor vent gas, 2) heavier semi-volatiles and pesticides appear to remain in the evaporator concentrate, 3) a very sharp bulk saturation transition occurs at about 10.1 M Na concentration (48.6 wt\%, or $94.6 \mathrm{~g}$ total solids/100 g water), and 4) an OLI model can generally describe organics distribution from the evaporation of Hanford simulant.

\section{REFERENCES}

1. Crawford, C.L., Crowder, M. L., Saito, H.H., Calloway T.B., "Evaporation of a Large Decontaminated Hanford Tank Sample", 2001 American Institute of Chemical Engineers Spring National Meeting, Novel Chemical Processing for Nuclear Materials Reclamation, Stabilization, and Storage: Part II, Paper No. 108a, Houston, TX, April 25, 2001. 
2. Klinger, G.S., Urie, M.W., Campbell, J.A.,Clauss, S.A., Hoppe, E.W., Mong, G.M., Sharma, A.K., "Organic Analysis of AW-101 and AN-107 Tank Waste”, PNWD-2461, BNFL-RPT-001, Rev. 1, August, 2000.

3. Fiskum, S.K., Kurath, D.E., Rapko, B.M., "Development and Demonstration of a Sulfate Precipitation Process for Hanford Waste Tank 241-AN-107”, PNWD-3050, BNFL-RPT-029, Rev. 0, Battelle, Pacific Northwest Division, Richland, WA, August, 2000. 